\title{
Examining the Effects of Mobbing and Role Uncertainty on the Performance of the Employees: Research on Logistics Companies ${ }^{1}$
}

\author{
Zafer ADIGÜZEL \\ Assoc. Prof. Dr, Istanbul Medipol University, \\ Medipol Business School \\ zadiguzel@medipol.edu.tr \\ Orcid ID: https://orcid.org/0000-0001-8743-356X \\ İrem KÜÇÜKOĞLU \\ Undergraduate Student, Istanbul Medipol University, \\ Medipol Business School \\ ireemkckglu@gmail.com \\ Orcid ID: https://orcid.org/0000-0003-0159-3621
}

\begin{abstract}
Within the scope of the research, when organizations position their employees according to their abilities and expertise, this can contribute positively to the performance and productivity of the employees. However, when the pressure is put on employees and when the duties and responsibilities are given out of their knowledge, the employees desire to leave the organization starts to emerge. In other words, in cases of mobbing and role uncertainty, individuals who lose control feel themselves under pressure and unwillingly work while performing their duties. This situation also destroys the passion of the employees for their jobs. SPSS 25 and AMOS programs were used to analyze the data. Firstly, factor and reliability analysis were performed in the analyzes, and after these analyzes, correlation analysis was performed to examine the relationships between variables, and regression analysis was performed to test hypotheses. As a result of the research, mobbing and role uncertainty reveal employees' intentions to leave and decrease their performance. Within the scope of the research model, data were collected from 321 employees in institutions operating in the service sector (logistics companies), and the relationships and effects between mobbing, role uncertainty, intention to leave, and employee performance were examined.
\end{abstract}

\footnotetext{
${ }^{1}$ Article Arrival/Acceptance Date: 13.04.2020 / 25.11.2020

Reference Information: Adıgüzel, Z. and Küçükoğlu, İ. (2021). Examining the effects of mobbing and role uncertainty on the performance of the employees: research on logistics companies. Kahramanmaraş Sütçü İmam University Journal of Social Sciences, 18(1), 434-455. DOI: 10.33437/ksusbd.719717
} 


\section{Z.Adıgüzel-İ.Kücü̈koğlu Examining the Effects of Mobbing and Role...}

Keywords: Mobbing, Role Uncertainty, Intention to Leave, Employee Performance.

\section{Çalışanların Yaşadıkları Mobbing ve Rol Belirsizliğinin Performanslarına Etkilerinin İncelenmesi: Lojistik Firmalarında Araştırma}

Öz

Yapılan araştırmalar kapsamında örgütler çalışanlarını yeteneklerine ve uzmanlıklarına göre konumlandırdıklarında, bu durum çalışanların performansına ve verimliliklerine olumlu yönde katkı sağlayabilmektedir. Ancak çalışanlara baskı uygulanmaya başlandığında, sahip oldukları bilgi birikimlerinin dışında görev ve sorumluluklar verildiğinde çalışanlarda örgütden ayrılma isteği oluşmaya başlamaktadır. Yani, mobbing ve rol belirsizliğinin olduğu durumlarda, kontrolü kaybeden bireyler, görevlerini yerine getirirken kendilerini baskı altında hissetmekte ve istemiyerek çalışmaktadırlar. Bu durum çalışanların işlerine olan tutkularını da yok etmektedir. Araştırmanın amacı hizmet sektöründe mobbing'in ve rol belirsizliğinin çalışanlar üzerindeki etkisini incelemek olduğundan, hizmet sektöründe (lojistik firmaları) faaliyetde bulunan firmalardaki 321 çalışandan veriler toplanarak mobbing, rol belirsizliği, işten ayrılma niyeti ve çalışan performansı arasındaki ilişkiler ve etkiler incelenmiştir. Verilerin analiz edilmesinde SPSS 25 ve AMOS programları kullanılmıştır. Analizlerde öncelikle faktör ve güvenirlilik analizi yapılmış olup, bu analizlerden sonra değişkenler arasındaki ilişkilerin incelenmesinde korelasyon analizi, hipotezlerin test edilmesinde regresyon analizi yapılmıştır. Araştırma sonucunda mobbing ve rol belirsizliğinin, çalışanların işten ayrılma niyetlerini arttırtığı ve çalışanların performanslarını düşürdüğü açıklanabilmektedir.

Anahtar Kelimeler: Mobbing, Rol Belirsizliği, İșten Ayrılma Niyeti, Çalışan Performans1.

\section{INTRODUCTION}

Organizations need to give importance to their employees to work with high efficiency in their work, while still focused on making profits balanced with sustainabile practices. Human resource departments have the feature of providing a quality workforce to ensure that organizations are sustainable (Orr and Orr, 2014). Organizations need to have an employee-oriented management approach in order to improve employee performance and eliminate their intention to leave the job. Employee satisfaction is at the forefront of an employee-oriented management approach. As employees feel peaceful and comfortable within their 
working environment, their commitment to their jobs and to the organization increases. At the same time, organizations should constantly renew and develop the technological infrastructure they use in order not to lag behind competitors. Those who work together with technological innovations can be adversely affected as if they were sent from organizations. While doing this, employees should feel comfortable and not fall into any uncertainty. However, as organizations develop themselves, the labor force should be used in the same way. Employees can also be more productive as a result of improving themselves and adapting to new developments with the training they receive. Indeed, organizational changes are necessary in order not to lag behind competitors, yet, researchers argue that organizational change negatively affects the workforce (Hoag et al., 2002; Oreg, 2006; Thomas and Hardy, 2011). The reason for this is the technology-driven changes that help organizations reduce their workforce. Thanks to technology, it is possible to leave the work done by the workforce to software-based machines/robots. In this case, if employees create new job opportunities for them, role uncertainty may arise. When employees adapt to the organization, their performance and participation at work increases. In addition, when employees' creative thoughts are supported, their burnout in their work decreases, and their intention to leave is eliminated (Wrzesniewski and Dutton, 2001). There are three different actions that affect the performance of employees: the positive or negative situation of the feedback expected from the managers, the extra responsibility given, and the different ways of performing the task to be fulfilled clarify the positive or negative thoughts of the employees about the organization (Demerouti and Peeters, 2018; Petrou et al., 2012). Individuals who intend to leave do so as a result of negative situations in their organizations. Within the scope of the research model, the relationships between mobbing, role uncertainty, intention to leave, and employee performance are examined. The structure of the research is primarily literature, and then methodology. After the analysis is specified in the Methodology section, the research ends with the discussion and the conclusion section.

\section{LITERATURE REVIEW}

\section{Mobbing}

A mobbing perception may differ according to the gender/belief/opinion/country of the employees. There is no socially acceptable and legally acceptable aspect of discrimination among employees due to these differences. Discrimination cannot be acceptable because of an individuals' beliefs and sexual identity. Discrimination is never a pleasant situation and varies according to race, belief, and political view. One of the most important factors for organizations to be successful is diversity. In other words, the correct management of organizational structures with different views adds richness to 


\section{Z.Adıgüzel-İ.Kücü̈koğlu Examining the Effects of Mobbing and Role...}

organizations (Shallcross et al., 2013). Accordingly, companies with high brand value attach importance to diversity. Particularly, when looking at companies with high brand value, such as Microsoft, Apple, Samsung, or Facebook, importance is given to the diversity of employees and to work within a peaceful organizational structure. The fact that employees in the organizations have the same social rights is an important factor, especially in any conflict between the employees or employer (Matyók and Schmitz, 2010). If discrimination among employees is to be prevented, the principle of equality between employees should be emphasized. Otherwise, it would be inevitable for employees to apply mobbing behaviors towards each other. In this case, as the level of unrest will increase within the organization, an increase will be observed in employee turnover. Employees who experience mobbing in their organizations, and according to employees in other institutions that do not experience mobbing,due to differences in location, status, and out-of-step wages (Duffy and Sperry, 2011), see that their job efficiency and performance decrease (Branch et al., 2001). The most obvious situation seen in organizations experiencing mobbing mostly occurs in the superior relations of the subordinate. Mobbing, which is carried out with an oppressive attitude towards employees, and that leads to leaving the company, causes employees to hate the organization and seek new job opportunities. This situation causes the employees to experience psychological problems, to experience negative performance and productivity, and results in employee flight (Qureshi et al., 2015). Within the scope of the research model, the effects of mobbing on employees' performance and intention to leave are examined.

\section{Role Uncertainty}

The uncertainty of the role that employees experience in their organizations is also reflected in the performance of the organization. Because the employees take responsibility for more than one task, the energy they spend on more than one task are different. This situation both creates unrest in employees and triggers the intention to leave. The productivity of the work done by employees who have confusion with role uncertainty also leads to a decrease in productivity. Organizations seek to achieve a financial balance i order to increase efficiency, but in order to achieve this, employees need to focus on their work (Christiano et al., 2014; Gilchrist and Jae, 2014). Anxiety, stress, fatigue, and role uncertainty experienced by the employees in the organization negatively affect the performance of the organization. One of the most important factors for employees who experience role uncertainty is the social environment, which has a significant impact on the individual and the organization (Christ and Burritt, 2015). Role uncertainty may also occur when employees are affected by the social environment. In the face of this situation, since employees feel pressured, thoughts such as a desire to leave the organization and change jobs are 
concentrated (Burritt and Schaltegger, 2010; Rodrigue et al., 2013). Employees who experience uncertainty may compromise the quality of their work due to the multiple workloads they are responsible for, and this can lead to customer dissatisfaction. Customer satisfaction, on the other hand, is high in organizational structures where employees are happy and peaceful. However, it is very difficult to say the same thing for employees who are not in a happy and peaceful working environment but rather working at an intensive business pace. One of the most important reasons for role uncertainty is that organizations have the idea of employing a small number of employees by calculating costs. Technologyoriented organizations can employ a small number of employees and achieve high productivity because they can ensure that their work is done through technologysupported processes. However, reducing the number of employees in jobs that employees have to do, and giving excessive workload to existing employees can be an important factor in experiencing role uncertainty. Environmental uncertainties pose a danger to the identity of the organization for each organization (Lewis and Harvey, 2001). In organizations with high levels of uncertainty, it is also difficult for managers to make decisions (Cadman et al., 2016). Therefore, the effects of the role uncertainty experienced by the employees on the performance of the employees and their intention to leave are examined within the scope of the research model.

\section{Employee Performance}

The degree of satisfaction of the employees in their work and their attitudes towards their jobs are reflected in their performance. Employees' energies at work, their loyalty to the organization, their integration with the organization, and their mentally positive or negative feelings while working in their organizations are associated with their performance. In the satisfaction levels of employees and their commitment to the organization, the level of stress, anxiety, mental and physical health they experience are important (Hakanen and Schaufeli, 2012; Imamura et al., 2016), andhe sincere involvement of employees in their work positively affects both the organization and their performance. The rate of participation of employees in the work they love to do is quite high (Rongen et al., 2014; Rich et al., 2010). Furthermore, the relationship between managers and employees also affects performance (Christian et al., 2011). Managers should be supporting employees (Halbesleben and Wheeler, 2008), innovation (Gorgievski et al., 2014), creativity (Demerouti et al., 2015), productivity (Xanthopoulou et al., 2009), and service quality (Salanova et al., 2005). Employees also have positive performance if they pursue management policies. Yet, contrary to those stated, when there is a management approach that decreases the performance of the employees, the organization is negatively affected by this situation. According to Sonnentag (2011), when employee loyalty increases, their participation in the job increases at a certain level, but argues that it affects the 


\section{Z.Adıgüzel-İ.Kücü̈koğlu Examining the Effects of Mobbing and Role...}

employee negatively after a certain level (Sonnentag, 2011). Because excessive workload decreases the performance of the employee and the intention to leave the work arises, it also determines the performance of the employees in the duties and responsibilities assigned to them. The uncertainty of the role of the employees in the face of excessive workload can also negatively affect their performance (Shimazu et al., 2015). Therefore, within the scope of the research model, it is analyzed how mobbing and role uncertainty that employees are likely to experience in their institutions affect their performance.

H1: Mobbing experienced by employees in institutions negatively affects employee performance

H3: The role uncertainty experienced by employees in organizations is effective on employee performance

\section{Intention to Leave}

In organizations, as a result of employee dissatisfaction, the process of seeking a new job that suits them due to individual thoughts is called the intention to leave (Siu et al., 2015). With the intention of leaving the job, employees both reduce their performance at work and want to leave their organization at the first opportunity (Bogossian et al., 2014). The intention to leave is realized due to the absence of a working environment that employees expect for certain activities (Park et al., 2017). Employee intention to leave may arise as a result of role uncertainty, job dissatisfaction, and perceptions of psychological violence (Kim et al., 2016). Employees who are unable to adapt to the organizational culture have difficulties in doing their jobs and cannot fulfill their duties, so the employees intend to leave the job (Bhanugopan and Fish, 2006; Ritchie et al., 2015). Excessive discipline, bureaucratic obstacles, management problems, and lack of communication between employees in organizations can also be counted as important problems that create the intention to leave. Factors that push employees to leave their jobs are those where they are unable to withstand a particular situation for extended periods of time because they are exposed to more stress than usual due to their environment and their working conditions within the organization (Ingledew et al., 1997; Pienaar, 2008). In organizations where there is no business circulation, the commitment of employees to the organization is very strong. One of the most important reasons for this is that their expectations are met and they are satisfied with their work. However, employees with a weak commitment to the Organization want to leave easily as soon as they find a new job because they are looking for new job opportunities (Gerstenberg, 2012; Chen et al., 2015). For the organization, human resources management and organizational behavior demonstrated by employees are important (Acevedo et al., 2014). Because organizations' successful performance and sustainability lies 
in the efficiency of human resources, employees with different positions come together for a single purpose of the organization (Andresen et al., 2014). As the employees are important for organizations, within the scope of the research model, the effect of psychological violence perception and role uncertainty on the intention to leave is examined.

H2: Mobbing experienced by employees in organizations increases the intention to leave

H4: The role uncertainty experienced by employees in organizations has an impact on intention to leave

\section{METHODOLOGY}

Questionnaires were collected from 321 administrative staff (white-collar) working in logistics companies. Since the surveys were collected between October 1, 2019 and November 30, 2019 with the permission of logistics companies, there was no need for an ethics committee decision. SPSS 25 and AMOS programs were used to analyze the data. Since the questionnaire was prepared on a 5-point Likert scale, firstly factor and reliability analyzes were conducted. After these analyzes, correlation and regression analyzes were performed. Survey questions consist of questions representing 4 variables. Mobbing scale, by Leymann and Gustafsson (1996), Leymann and Zapf (1996), Einarsen and Raknes, (1997), Einarsen et al. (2009) developed questions are used. In the intention to leave scale, the questions were developed by Mobley et al. (1978), Örücü and Özafşarlıoğlu (2013), Polat and Meydan (2010), Sökmen and Mete (2015). In the Employee Performance scale,it was created by Rahman and Bullock (2004), Şehitoğlu and Zehir (2010) by making use of their work in their years. In Role Uncertainty, the questions were developed by Rizzo et al. (1970) and Erigüç (1994) making use of their work. Scales; The 5-point Likert scale ranged from "absolutely agree" to "absolutely disagree". 232 (72\%) male and 89 (28\%) female white-collar respondents answered the questionnaire. While 122 (38\%) of the participants were between 30-40 age groups; 171 (53\%) were in the 41-50 age group. The number of managers over the age of 51 was 28 (9\%), while 302 (94\%) of the employees who answered the questionnaire were university graduates, and $19(6 \%)$ had a master's degree.

\section{Research Goal}

The research was carried out on administrative staff working in various departments of companies (logistics companies) operating in the service sector: that is white-collar workers. It was aimed at collecting data from employees in the service sector, which is one of the sectors where stress and workload are high, 


\section{Z.Adıgüzel-İ.Kücü̈koğlu Examining the Effects of Mobbing and Role...}

in order to analyze the attitudes and behaviors of the individuals working in a very busy work tempo.

\section{Research Framework}

Since quantitative research has been carried out, it may be necessary to have a research model in order to analyze the data obtained and to show the results of the hypotheses defended as a result of the analyzes. For this reason, a research model was created based on the literature review to show how the variables affect the direction (Thomas et al., 2015).

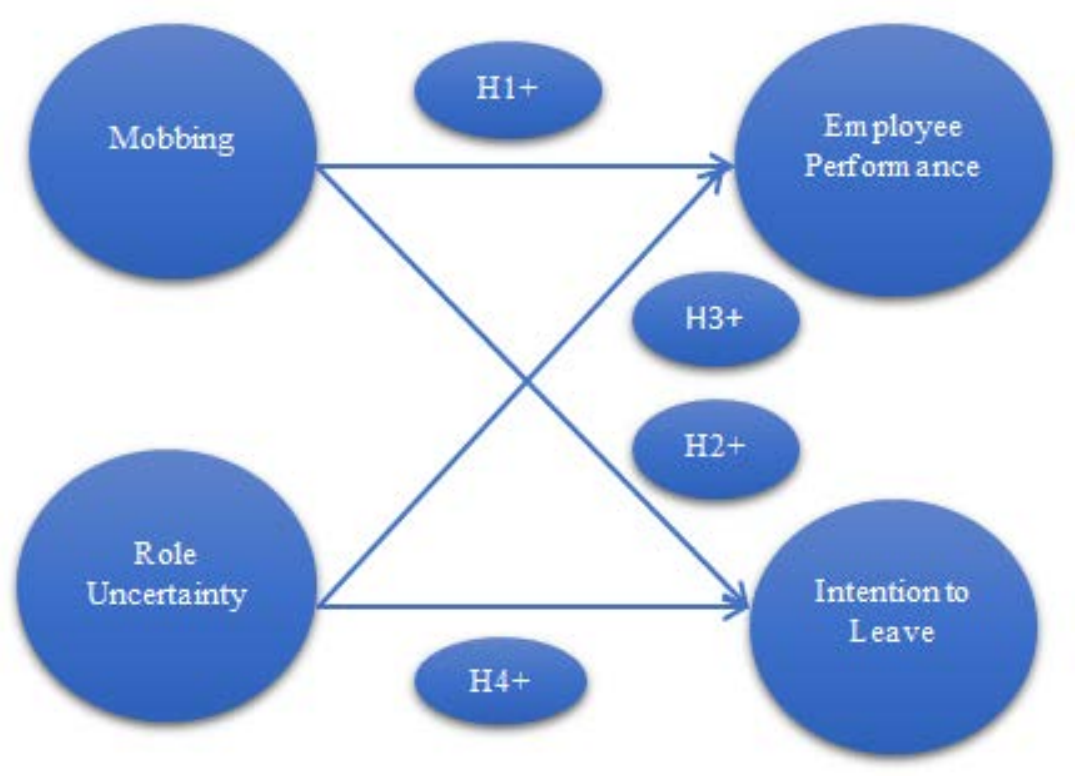

Figure 1. Research Model

\section{ANALYSIS}

Before factor analysis, the suitability of Kaisen-Meyer-Olkin (KMO) and Bartlett Sphericity Test is checked. The KMO value varies between 0 and 1 , and the KMO value of 1 indicates that variables can be estimated without errors. As a result of the Kaiser-Meyer-Olkin test, it is interpreted that factor analysis cannot be continued if the value is less than 0.50 (Bandalos and Finney, 2018). Since the $\mathrm{KMO}$ value was higher than $0.50(\mathrm{KMO}=0.934)$ and the Bartlett test was significant at 0.00 , the data set was found to be suitable for factor analysis (Cokluk et al., 2012). 
Table 1. Rotated Component Matrix ${ }^{\mathrm{a}}$

\begin{tabular}{|l|c|c|c|c|}
\hline \multicolumn{5}{|c|}{ Rotated Component Matrixa } \\
\hline
\end{tabular}




\section{Z.Adıgüzel-İ.Kücükoğlu Examining the Effects of Mobbing and Role...}

\begin{tabular}{|l|l|l|l|}
$\begin{array}{l}\text { RB3. I am competent in the work I do at the company I } \\
\text { work for. }\end{array}$ & & .690 \\
\hline $\begin{array}{l}\text { Extraction Method: Principal Component Analysis. } \\
\text { Rotation Method: Varimax with Kaiser Normalization. }\end{array}$ \\
\hline a Rotation converged in 6 iterations. \\
\hline
\end{tabular}

PSA: Mobbing, IAN: Intention to Leave, CPO: Employee Performance, RB: Role Uncertainty

Confirmatory Factor Analysis; It is used to define statistical analysis in research models that have more than one variable and more than one measured or observed variables (Keith and Reynolds, 2018).

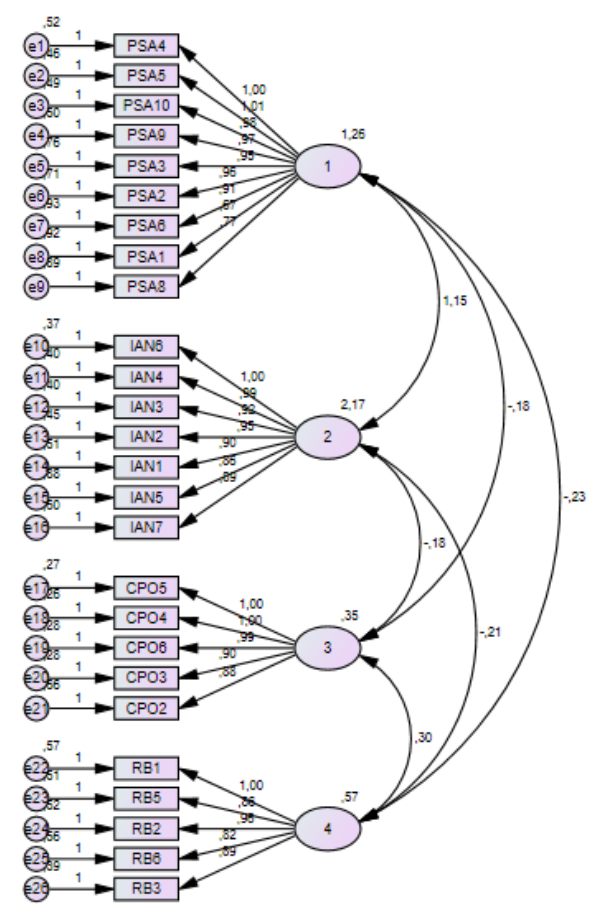

PSA: Mobbing, IAN: Intention to Leave, CPO: Employee Performance, RB: Role Uncertainty

Figure 2. Confirmatory Factor Analysis

Values accepted for confirmatory factor analysis in SPSS AMOS are compatible with the research model when looking at the values in Model Fit; $\mathrm{X} 2 / \mathrm{df}=3.147<5, \quad 0.85<\mathrm{GFI}=0.883, \quad 0.90<\mathrm{IFI}=0.915, \quad 0.90<\mathrm{NFI}=0.920$, $0.90<\mathrm{CFI}=0.915$, RMSEA $=0.060<0.080$. For this reason, Along with the 
confirmatory factor analysis, the results obtained in the explanatory factor analysis were confirmed.

In the reliability analysis, considering the results obtained from factor analysis and the changes made, alpha coefficients were examined for each variable of the study and their consistency was examined. Reliability analysis data for variables are shown in Table 2.

Table 2. Reliability Analysis

\begin{tabular}{|c|c|c|}
\hline Variables & Number of Questions & Cronbach Alpha ( $\boldsymbol{\alpha})$ Values \\
\hline Mobbing & 9 & .931 \\
\hline Role Uncertainty & 5 & .821 \\
\hline $\begin{array}{c}\text { Employee } \\
\text { Performance }\end{array}$ & 5 & .817 \\
\hline Intention to Leave & 7 & .962 \\
\hline
\end{tabular}

The method that helps determine the level and direction of relationship between the two variables is called correlation analysis. In other words, correlation is the method that reveals the magnitude, direction, and importance of the relationship between the two variables. The Pearson Correlation used in the study is used to determine whether there is a relationship between the two variables. The Pearson coefficient is symbolized by the letter " $r$ ", varies between $\mathrm{r}-1$ and $\mathrm{r}+1$, and indicates that the strength of the relationship between the two variables increases as we approach 1 (Gogtay and Thatte, 2017).

Pearson correlation coefficients, mean, standard deviation, and correlation analysis results of the variables in the model are given. Standard deviation values of variables are calculated and it shows that the amount of variance (variability) between these values is sufficient for valid analysis (Cohen et al., 2013).

Table 3. Correlations

\begin{tabular}{|l|l|r|r|r|r|}
\hline \multicolumn{2}{|c|}{ Correlations } \\
\hline \multirow{2}{|c|}{} & & $\begin{array}{c}\text { Employee } \\
\text { Emobing } \\
\text { Performance }\end{array}$ & $\begin{array}{c}\text { Role } \\
\text { Uncertainty }\end{array}$ & $\begin{array}{c}\text { Intention } \\
\text { to Leave }\end{array}$ \\
\hline \multirow{4}{*}{ Mobbing } & Pearson Correlation & 1 & $-.304^{* *}$ & $-.260^{* *}$ & $.666^{* *}$ \\
\cline { 2 - 7 } & Sig. (2-tailed) & & 0,000 & 0.000 & 0.000 \\
\cline { 2 - 7 } & $\mathrm{N}$ & 321 & 321 & 321 & 321 \\
\hline \multirow{2}{*}{$\begin{array}{l}\text { Employee } \\
\text { Performance }\end{array}$} & Pearson Correlation & $-.304^{* *}$ & & $-.552^{* *}$ & $-.242^{* *}$ \\
\cline { 2 - 7 } & Sig. (2-tailed) & 0.000 & & 0.000 & 0.000 \\
\hline
\end{tabular}


$\underline{\text { Z.Adıgüzel-İ.Kücükoğlu } \quad \text { Examining the Effects of Mobbing and Role... }}$

\begin{tabular}{|l|l|r|r|r|r|} 
& $\mathrm{N}$ & 321 & 321 & 321 & 321 \\
\hline \multirow{3}{*}{$\begin{array}{l}\text { Role } \\
\text { Uncertainty }\end{array}$} & Pearson Correlation & $-.260^{* *}$ & $-.552^{* *}$ & 1 & $.177^{* *}$ \\
\cline { 2 - 6 } & Sig. (2-tailed) & 0.000 & 0.000 & & 0.001 \\
\cline { 2 - 6 } & $\mathrm{N}$ & 321 & 321 & 321 & 321 \\
\hline \multirow{2}{*}{$\begin{array}{l}\text { Intention to } \\
\text { Leave }\end{array}$} & Pearson Correlation & $.666^{* *}$ & $-.242^{* *}$ & $.177^{* *}$ & 1 \\
\cline { 2 - 6 } & Sig. (2-tailed) & 0.000 & 0.000 & 0.001 & 321 \\
\cline { 2 - 6 } & $\mathrm{N}$ & 321 & 321 & 321 & 3 \\
\hline \multirow{2}{*}{ **. Correlation is significant at the 0.01 level (2-tailed). } \\
\hline
\end{tabular}

As a result of the correlation analysis, it can be seen that mobbing and role uncertainty variables decrease employee performance. That is, there is a negative relationship: they increase the intention to leave a positive relationship. Regression analysis was used to test the predicted research hypotheses, and the 4 hypotheses accepted according to the results of these regression analyzes are shown in Table 4.

Table 4. Regression Analysis Results

\begin{tabular}{|c|c|c|c|c|}
\hline Hypotheses & Standard $\beta$ & Sig. & $\begin{array}{l}\text { Supported / } \\
\text { Not Supported }\end{array}$ & $\begin{array}{l}\text { Level of } \\
\text { Significance } \\
\text { (Sig.) }\end{array}$ \\
\hline $\begin{array}{l}\text { H1: Mobbing experienced by } \\
\text { employees in institutions } \\
\text { negatively affects employee } \\
\text { performance }\end{array}$ & $.304 * * *$ & 0.000 & Supported & $\mathrm{p}<0.001$ \\
\hline $\begin{array}{l}\text { H2: Mobbing experienced by } \\
\text { employees in organizations } \\
\text { increases the intention to leave }\end{array}$ & $.666^{* * *}$ & 0.000 & Supported & $\mathrm{p}<0.001$ \\
\hline $\begin{array}{l}\text { H3: The role uncertainty } \\
\text { experienced by employees in } \\
\text { organizations is effective on } \\
\text { employee performance }\end{array}$ & $-.552 * * *$ & 0.000 & Supported & $\mathrm{p}<0.001$ \\
\hline $\begin{array}{l}\text { H4: The role uncertainty } \\
\text { experienced by employees in } \\
\text { organizations has an impact on } \\
\text { intention to leave }\end{array}$ & $.177 * * *$ & 0.000 & Supported & $\mathrm{p}<0.001$ \\
\hline
\end{tabular}

As a result of the regression analysis, hypotheses are supported as shown in table 4. Literature research and analysis results support each other. 


\section{DISCUSSION}

Employees may intend to leave their jobs according to the level of dissatisfaction due to both environmental factors and problems in organizations (Andresen et al., 2014; Bhaskar-Shrinivas et al., 2005). It is accepted that one of the reasons why employees are not satisfied with their organizations is mobbing: the psychological violence experienced by the employees triggers the intention to leave and they start to look for new job opportunities. For example, Tanriverdi et al. (2018) concluded in their research that mobbing increases the intention to leave. In addition, Kesebir (2018) states in research that mobbing has a negative effect on performance. Organizations need to be arranged in a way to prioritize employee circulation in order to prioritize the working conditions and employee satisfaction. Employees in organizations managed with this understanding establish a strong bond with their work by adapting to the organization (Bhatti et al., 2013). At the same time, those who are in the management level of organizations should avoid giving different duties and responsibilities to the employees. Otherwise, when employees start to experience role uncertainty, their performance begins to decrease and they are dissatisfied with their work. For example, Ozbozkurt and Ozbozkurt (2019) concluded in their study that role uncertainty negatively affects job performance. Therefore, employees can be affected psychologically by their position, work, and organizational environment (Warr, 1987). In order for the employees to be productive in the organizations, the working conditions in the organizations should be regulated without stress and focus on performance-oriented outcomes. Employees want their workplace to be a free environment, with autonomous work, that is, after defining their duties and responsibilities, where trust is at the forefront and there are no impositions. Therefore, the expectations of the employees from the organization should be the goal: providing social support, contributing to the development of their skills, discovering their abilities and the tasks assigned to them that are positively related to their work (Warr, 1994). If employees are satisfied with their organizations, there is a high level of participation in the job. This situation also shows the value given to the employees. Because employees do not only expect wages in return for their labor, they also want to see value. Otherwise, there is an increase in the intention to leave the employees in a management approach that makes them feel worthless. In working conditions where employees are not valued and exposed to psychological violence, adverse effects, such as health problems, may occur (Maslach, 2011). Every psychological pressure on employees reduces the performance of the employees at work. The commitment of employees to their organizations shows their satisfaction with their work, both physically and psychologically. For this reason, attention should be paid to avoid employees experiencing situations that might lead to a role of uncertainty and an atmosphere of mobbing. Organizations need to pay more attention to employees and working conditions in order to continue their activities in a sustainable 


\section{Z.Adıgüzel-İ.Kücü̈koğlu Examining the Effects of Mobbing and Role...}

structure. Otherwise, the stress of the working environment or the dissatisfaction of the employees with their work triggers the idea of leaving the job (Ruzungunde et al., 2016).

\section{CONCLUSION}

The mobbing that employees are experiencing is necessary to be seen as a situation developed by the economic changes that took place after the 1970s: the changes in the quality of the working environment in the workplaces, especially the capitalist profit understanding and competition; and the form of precarious employment and the capitalist competition created by the flexible production forms defined as post-fordists. The crises experienced in this economic and political ground, the unemployment it creates, overwork, and intimidating behavior and pressure are the basis for the increase. Studies show that high unemployment rates and a low value of employees cause increased mobbing. In short, "mobbing" emerges and increases as a natural result of neo-liberal policies that have marked the last two decades and have been implemented in all sectors. It is stated that "mobbing" is mostly related to the ego of the managers, the nondemocratic quality of the working environment, the existing leadership style (especially the incompatibility between the manager and the employee within the organization), and negative relations and communication between the employees. In this sense, it is not an exaggeration to claim that the social values dominated by capitalist culture trigger mobbing and increasingly create physical and emotional damage. In this way, it should be seen that "intimidation" is a class character and a process involving racial and gender inequalities. In the research result, we can see that mobbing increases employees' intention to leave and negatively affects their performance. This situation emerges as the reaction of the employees in an environment where they do not feel comfortable. Limited data in this area show that mobbing is not an unusual situation both in the USA and in Europe. It is reported that approximately one in six employees (16.8\%) in the USA is the victim of mobbing in the workplace. In a study involving public employees in the USA, it is stated that $42 \%$ of female employees and $15 \%$ of male employees have been exposed to emotional harassment and bullying in the workplace in recent years, and 15\% of suicides in Sweden are caused by mobbing. It can be understood that mobbing is a psychological condition that should not be underestimated. Instead of displaying an oppressive management approach to employees, it is a smarter to find a solution to the question of how to get the best efficiency from the employees. Indeed, mobbing can be seen more frequently in some professions. In a study conducted in healthcare workers in Taiwan, the prevalence of mobbing was found to be $50.9 \%$ for the past year, and it was stated that it was seen at a higher rate than verbal and physical violence. In a study conducted in healthcare workers in Bosnia again, $76 \%$ of individuals were reported to have been exposed to mobbing behavior, while $26 \%$ were found to be 
persistent and repetitive. It was also noted that this was related to the development of mental disorders. Considering the limitations of the study, it is beneficial to carry out such studies, especially on blue-collar workers since it is done in a certain sample population. In future studies, we assume that it will be possible to add new concepts to the literature with data collected from blue-collar workers working in different sectors with open-ended questions. We believe that it is beneficial to focus on the thoughts of the employees as open-ended questions can provide better answers than the questionnaires.

\section{REFERENCES}

Acevedo, B. P., Aron, E. N., Aron, A., Sangster, M. D., Collins, N. and Brown, L. L. (2014). The highly sensitive brain: an fMRI study of sensory processing sensitivity and response to others' emotions. Brain and Behavior, 4(4), 580-594.

Andresen, M., Bergdolt, F., Margenfeld, J. and Dickmann, M. (2014). Addressing international mobility confusion-developing definitions and differentiations for self-initiated and assigned expatriates as well as migrants. The International Journal of Human Resource Management, 25(16), 2295-2318.

Aydin, O. and Ocel, H. (2009). Isyeri zorbaligi olcegi: gecerlik ve guvenirlik calismasi. Turk Psikoloji Yazilari, 12(24), 94-103.

Bandalos, D. L. and Finney, S. J. (2018). Factor analysis: Exploratory and confirmatory, In The reviewer's guide to quantitative methods in the social sciences (pp. 98-122). Routledge.

Bhanugopan, R. and Fish, A. (2006). An empirical investigation of job burnout among expatriates. Personnel Review, 35(4), 449-468.

Bhaskar-Shrinivas, P., Harrison, D. A., Shaffer, M. A. and Luk, D. M. (2005). Input-based and time-based models of international adjustment: Metaanalytic evidence and theoretical extensions. Academy of Management Journal, 48(2), 257-281.

Bhatti, M. A., Kaur, S. and Battour, M. M. (2013). Effects of individual characteristics on expatriates' adjustment and job performance. European Journal of Training and Development, 37(6), 544-563.

Bogossian, F., Winters-Chang, P. and Tuckett, A. (2014). The Pure Hard Slog That Nursing Is: A Qualitative Analysis of Nursing Work. Journal of Nursing Scholarship, 46(5), 377-388. 


\section{Z.Adıgüzel-İ.Kücü̈koğlu Examining the Effects of Mobbing and Role...}

Branch, S., Ramsay, S. and Barker, M. (2013). Workplace bullying, mobbing and general harassment: A review. International Journal of Management Reviews, 15(3), 280-299.

Burritt, R. L. and Schaltegger, S. (2010). Sustainability accounting and reporting: fad or trend?. Accounting, Auditing \& Accountability Journal, 23(7), 829846.

Buyukozturk, S. (2011). Sosyal Bilimler icin Veri Analizi El Kitabl, Pegem Akademi.

Cadman, T., Maraseni, T., Breakey, H., López-Casero, F. and Ma, H. (2016). Governance values in the climate change regime: Stakeholder perceptions of REDD+ legitimacy at the national level. Forests, 7(10), 1-17.

Chen, S., Westman, M. and Hobfoll, S. E. (2015). The commerce and crossover of resources: Resource conservation in the service of resilience. Stress and Health, 31(2), 95-105.

Christ, K. L. and Burritt, R. L. (2015). Material flow cost accounting: a review and agenda for future research. Journal of Cleaner Production, 108, 13781389.

Christian, M. S., Garza, A. S. and Slaughter, J. E. (2011). Work engagement: A quantitative review and test of its relations with task and contextual performance. Personnel Psychology, 64(1), 89-136.

Christiano, L. J., Motto, R. and Rostagno, M. (2014). Risk shocks. American Economic Review, 104(1), 27-65.

Cohen, J., Cohen, P., West, S. G. and Aiken, L. S. (2013). Applied multiple regression/correlation analysis for the behavioral sciences, Routledge.

Cokluk, O., Sekercioglu, G. and Buyukozturk, S. (2018). Sosyal bilimler için cok degiskenli istatistik: SPSS ve LISREL uygulamalarl, Pegem Akademi.

Demerouti, E. and Peeters, M. C. (2018). Transmission of reduction-oriented crafting among colleagues: A diary study on the moderating role of working conditions. Journal of Occupational and Organizational Psychology, 91(2), 209-234.

Demerouti, E., Bakker, A. B. and Gevers, J. M. (2015). Job crafting and extrarole behavior: The role of work engagement and flourishing. Journal of Vocational Behavior, 91, 87-96. 
Duffy, M. and Sperry, L. (2011). Mobbing: Causes, consequences, and solutions, Oxford University Press.

Einarsen, S. and Raknes, B. I. (1997). Harassment in the workplace and the victimization of men. Violence and Victims, 12(3), 247.

Einarsen, S., Hoel, H. and Notelaers, G. (2009). Measuring exposure to bullying and harassment at work: Validity, factor structure and psychometric properties of the Negative Acts Questionnaire-Revised. Work \& Stress, 23(1), 24-44.

Erigüc, K. G. (1994). Hastanelerde personelin işle ilgili tutumlart personel devri: Ankara Ili ornegi, Yayımlanmış Doktora Tezi, Hacettepe Universitesi Saglik Bilimleri Enstitusu.

Gerstenberg, F. X. (2012). Sensory-processing sensitivity predicts performance on a visual search task followed by an increase in perceived stress. Personality and Individual Differences, 53(4), 496-500.

Gilchrist, S. and Jae, W. (2014). Sim, and Egon Zakrajšek. Uncertainty, financial frictions, and investment dynamics, National Bureau of Economic Research.

Gogtay, N. J. and Thatte, U. M. (2017). Principles of correlation analysis. Journal of the Association of Physicians of India, 65(3), 78-81.

Gorgievski, M. J., Moriano, J. A. and Bakker, A. B. (2014). Relating work engagement and workaholism to entrepreneurial performance. Journal of Managerial Psychology, 29(2), 106-121.

Hakanen, J. J. and Schaufeli, W. B. (2012). Do burnout and work engagement predict depressive symptoms and life satisfaction? A three-wave sevenyear prospective study. Journal of Affective Disorders, 141(2-3), 415-424.

Halbesleben, J. R. and Wheeler, A. R. (2008). The relative roles of engagement and embeddedness in predicting job performance and intention to leave. Work \& Stress, 22(3), 242-256.

Hoag, B. G., Ritschard, H. V. and Cooper, C. L. (2002). Obstacles to effective organizational change: The underlying reasons. Leadership \& Organization Development Journal, 23(1), 6-15.

Imamura, K., Kawakami, N., Inoue, A., Shimazu, A., Tsutsumi, A., Takahashi, M. and Totsuzaki, T. (2016). Work engagement as a predictor of onset of Major Depressive Episode (MDE) among workers, independent of 


\section{Z.Adıgüzel-İ.Kücü̈koğlu Examining the Effects of Mobbing and Role...}

psychological distress: a 3-year prospective cohort study. PloS One, 11(2), $1-14$.

Ingledew, D. K., Hardy, L. and Cooper, C. L. (1997). Do resources bolster coping and does coping buffer stress? An organizational study with longitudinal aspect and control for negative affectivity. Journal of Occupational Health Psychology, 2(2), 118-133.

Keith, T. Z. and Reynolds, M. R. (2018). Using confirmatory factor analysis to aid in understanding the constructs measured by intelligence tests, In D. P. Flanagan \& E. M. McDonough (Eds.), Contemporary intellectual assessment: Theories, tests, and issues (p. 853-900). The Guilford Press.

Kesebir, M. (2018). Mobbing'in Calisanlarin Performansi Uzerine Etkisi: Istanbul'da Bankacilik Sektoru Uzerine Bir Uygulama. Usak Universitesi Sosyal Bilimler Dergisi, 11(2), 154-169.

Kim, T. Y., Lee, D. R. and Wong, N. Y. S. (2016). Supervisor humor and employee outcomes: The role of social distance and affective trust in supervisor. Journal of Business and Psychology, 31(1), 125-139.

Lewis, G. J. and Harvey, B. (2001). Perceived environmental uncertainty: The extension of Miller's scale to the natural environment. Journal of Management Studies, 38(2), 201-234.

Leymann, H. (1993). Mobbing-Psychoterror am Arbeitsplatz und Wie Man Sich Dagegen Wehren Kann,(Mobbing-Psychological Terror at Work, and How One Can Defend Oneself), Rowohlt.

Leymann, H. (1996). The content and development of mobbing at work. European Journal of Work and Organizational Psychology, 5(2), 165-184.

Leymann, H. and Gustafsson, A. (1996). Mobbing at work and the development of post-traumatic stress disorders. European Journal of Work and Organizational Psychology, 5(2), 251-275.

Leymann, H. and Zapf, D. (Eds.). (1996). Mobbing and victimization at work (No. 2), Psychology Press.

Maslach, C. (2011). Engagement research: Some thoughts from a burnout perspective. European Journal of Work and Organizational Psychology, 20(1), 47-52. 
Matyók, T. and Schmitz, C. L. (2010). A story to tell: Bullying and mobbing in the workplace. International Journal of Business and Social Science, 1(3), 87-97.

Mobley, W. H., Horner, S. O. and Hollingsworth, A. T. (1978). An evaluation of precursors of hospital employee turnover. Journal of Applied Psychology, 63(4), 408.

Naktiyok, A. (2004). Íç girisimcilik, Beta Yayinlari.

Oreg, S. (2006). Personality, context, and resistance to organizational change. European Journal of Work and Organizational Psychology, 15(1), 73-101.

Orr, L. M. and Orr, D. J. (2014). Eliminating Waste in Business: Run Lean, Boost Profitability, Apress.

Orucu, E. and Ozafsarlioglu, S. (2013). Orgutsel Adaletin Calisanlarin Isten Ayrilma Niyetine Etkisi: Guney Afrika Cumhuriyetinde Bir Uygulama/The Influence of Organizational Justice on the Turnover Intention: A Study in the Republic of South Africa. Mustafa Kemal Üniversitesi Sosyal Bilimler Enstitüsü Dergisi, 10(23), 335-358.

Ozbozkurt, O. B. and Ozbozkurt, N. (2019). Rol Belirsizligi ve Rol Catismasinin İş Performansina Etkisinde İş Tatmininin Aracılık Rolü: Mersin Ilinde Faaliyette Bulunan Özel Hastaneler Üzerine Bir Araştirma. Anemon Muş Alparslan Universitesi Sosyal Bilimler Dergisi, 7(4), 1-1.

Park, J., Yoon, S., Moon, S. S., Lee, K. H. and Park, J. (2017). The effects of occupational stress, work-centrality, self-efficacy, and job satisfaction on intent to quit among long-term care workers in Korea. Home Health Care Services Quarterly, 36(2), 96-111.

Petrou, P., Demerouti, E., Peeters, M. C., Schaufeli, W. B. and Hetland, J. (2012). Crafting a job on a daily basis: Contextual correlates and the link to work engagement. Journal of Organizational Behavior, 33(8), 1120-1141.

Pienaar, J. (2008). Skeleton key or siren song: is coping the answer to balancing work and well-being?. The individual in the changing working life, (pp. 235-257), Cambridge University Press.

Polat, M. and Meydan, C. H. (2010). Örgütsel özdeşleşmenin sinizm ve işten ayrılma niyeti ile ilişkisi üzerine bir araştırma. Savunma Bilimleri Dergisi, 9(1), 145-172. 


\section{Z.Adıgüzel-İ.Kücü̈koğlu Examining the Effects of Mobbing and Role...}

Qureshi, M. I., Iftikhar, M., Janjua, S. Y., Zaman, K., Raja, U. M. and Javed, Y. (2015). Empirical investigation of mobbing, stress and employees' behavior at work place: quantitatively refining a qualitative model. Quality \& Quantity, 49(1), 93-113.

Rahman, S. U. and Bullock, P. (2005). Soft TQM, hard TQM, and organisational performance relationships: an empirical investigation. Omega, 33(1), 7383.

Rich, B. L., Lepine, J. A. and Crawford, E. R. (2010). Job engagement: Antecedents and effects on job performance. Academy of Management Journal, 53(3), 617-635.

Ritchie, W., Brantley, B. I., Pattie, M., Swanson, B. and Logsdon, J. (2015). Expatriate Cultural Antecedents and Outcomes: An Assessment Tool for Nonprofit Managers. Nonprofit Management and Leadership, 25(3), 325342.

Rizzo, J. R., House, R. J. and Lirtzman, S. I. (1970). Role conflict and ambiguity in complex organizations. Administrative Science Quarterly, 15(2), 150163.

Rodrigue, M., Magnan, M. and Boulianne, E. (2013). Stakeholders' influence on environmental strategy and performance indicators: A managerial perspective. Management Accounting Research, 24(4), 301-316.

Rongen, A., Robroek, S. J., Schaufeli, W. and Burdorf, A. (2014). The contribution of work engagement to self-perceived health, work ability, and sickness absence beyond health behaviors and work-related factors. Journal of Occupational and Environmental Medicine, 56(8), 892897.

Ruzungunde, V. S., Murugan, C. and Hlatywayo, C. K. (2016). The influence of job stress on the components of organisational commitment of health care personnel in the Eastern Cape province South Africa. International Business \& Economics Research Journal (IBER), 15(5), 219-226.

Salanova, M., Agut, S. and Peiró, J. M. (2005). Linking organizational resources and work engagement to employee performance and customer loyalty: the mediation of service climate. Journal of Applied Psychology, 90(6), 12171227. 
Sehitoglu, Y. and Zehir, C. (2010). Turk kamu kuruluslarinda calisan performansinin, calisan sessizligi ve orgutsel vatandaslik davranisi baglaminda incelenmesi. Amme Idaresi Dergisi, 43(4), 87-110.

Shallcross, L., Ramsay, S. and Barker, M. (2013). Severe workplace conflict: The experience of mobbing. Negotiation and Conflict Management Research, 6(3), 191-213.

Shimazu, A., Schaufeli, W. B., Kamiyama, K. and Kawakami, N. (2015). Workaholism vs. work engagement: The two different predictors of future well-being and performance. International Journal of Behavioral Medicine, 22(1), 18-23.

Siu, O. L., Cheung, F. and Lui, S. (2015). Linking positive emotions to work well-being and turnover intention among Hong Kong police officers: The role of psychological capital. Journal of Happiness Studies, 16(2), 367380.

Sokmen, A. and Mete, E. S. (2016). Bezdirinin Is Performansi, Is Tatmini Ve Isten Ayrilma Niyeti Uzerindeki Etkisi: Ankara'da Bir Arastirma. Gazi Universitesi Iktisadi ve Idari Bilimler Fakültesi Dergisi, 17(3), 271-295.

Sonnentag, S. (2011). Research on work engagement is well and alive. European Journal of Work and Organizational Psychology, 20(1), 29-38.

Tanriverdi, H., Kocaslan, G. and Tastan, N. O. (2018). Psikolojik siddet algisi, tukenmislik sendromu ve isten ayrilma niyeti arasındaki iliski: Banka calisanlari uzerinde bir arastirma. Yonetim ve Ekonomi, 25(1), 113-131.

Thomas, J. R., Nelson, J. K. and Silverman, S. J. (2015). Research methods in physical activity, Human kinetics.

Thomas, R. and Hardy, C. (2011). Reframing resistance to organizational change. Scandinavian Journal of Management, 27(3), 322-331.

Warr, P. (1987). Work, unemployment, and mental health, Oxford University Press.

Warr, P. (1994). A conceptual framework for the study of work and mental health. Work \& Stress, 8(2), 84-97.

Wrzesniewski, A. and Dutton, J. E. (2001). Crafting a job: Revisioning employees as active crafters of their work. Academy of Management Review, 26(2), 179-201. 


\section{Z.Adıgüzel-İ.Kücükoğlu Examining the Effects of Mobbing and Role...}

Xanthopoulou, D., Bakker, A. B., Demerouti, E. and Schaufeli, W. B. (2009). Work engagement and financial returns: A diary study on the role of job and personal resources. Journal of Occupational and Organizational Psychology, 82(1), 183-200. 